\title{
Modification by Beta-Adrenergic Blockade of the Circulatory Responses to Acute Hypoxia in $\operatorname{Man} *$
}

\author{
David W. Richardson, $†$ Hermes A. Kontos, A. Jarrell Raper, and \\ Joh N L. Patterson, JR.市 \\ (From the Department of Medicine, Medical College of Virginia, Richmond, Va.)
}

\begin{abstract}
Summary. In 17 healthy men, beta-adrenergic blockade reduced significantly the tachycardia and the elevation of cardiac output associated with inhalation of $7.5 \%$ oxygen for 7 to 10 minutes.

Hypoxia did not increase plasma concentrations of epinephrine or norepinephrine in six subjects. Furthermore, blockade of alpha and beta receptors in the forearm did not modify the vasodilation in the forearm induced by hypoxia, providing pharmacologic evidence that hypoxia of the degree and duration used was not associated with an increase in the concentrations of circulating catecholamines in man.

Part of the increase in cardiac output and heart rate during acute hypoxia in man is produced by stimulation of beta-adrenergic receptors, probably by cardiac sympathetic nerves. The mechanism of the vasodilation in the forearm during hypoxia remains uncertain.
\end{abstract}

\section{Introduction}

Acutely induced hypoxia in man produces an increase in cardiac output, in heart rate, and in forearm blood flow (1) and a decrease in blood flow to the hand (2), but little change in arterial pressure. The mechanisms by which hypoxia produces these circulatory changes remain incompletely understood. A striking similarity exists between these circulatory responses and those produced by intravenous infusion of epinephrine ( 3 , 4). It has been suggested (1) that liberation of epinephrine contributes to the circulatory responses

* Submitted for publication January 10, 1966; accepted September 22, 1966.

Supported by grant DA MD 49-193-65-9153 from the U. S. Army Research and Development Command, Office of the Surgeon General, Department of the Army, and in part by grants H-3361, HTS-5573, and FR 00016-02 from the National Institutes of Health.

† Occupant of Virginia Heart Association Chair of Cardiovascular Research.

Address requests for reprints to Dr. David W. Richardson, Dept. of Medicine, Medical College of Virginia, Richmond, Va. 23219.

$\ddagger$ Recipient of National Heart Institute Research Career Award. to hypoxia, although recent measurement of serum catecholamine concentration during hypoxia in the dog shows little change (5). These considerations led us to study the influences of the sympathetic nervous system and of catecholamines as possible mediators of the circulatory responses to acute hypoxia.

Three approaches to evaluation of the contribution of circulating catecholamines and of sympathetic neural activity during hypoxia are used: 1) blockade of the positive chronotropic and inotropic cardiac effects of sympathetic nerve activity and of circulating catecholamines by use of betaadrenergic blocking agents, 2) measurement of the concentration of catecholamines in arterial blood during hypoxia, and 3) local blockade of alphaand beta-adrenergic receptors in forearm blood vessels.

\section{Methods}

Subjects were 30 healthy male volunteers, aged 19 to 39 years. All experiments were performed in an air-conditioned laboratory (room temperature, 23 to $24^{\circ} \mathrm{C}$ ) with the subjects recumbent on a table.

Cardiac output was measured by an indicator-dilution method. Through a 3-inch polyethylene catheter, in- 
serted in an antecubital vein and advanced into the median basilic vein, a known amount of indocyanine green was injected rapidly, and immediately followed by $20 \mathrm{ml}$ of isotonic saline injected into the vein in 2 or 3 seconds. Injection of dye into an antecubital vein has been shown by Bousvaros and others (6-8) to give values for cardiac output equal to those obtained by injection into the pulmonary artery or right atrium if the injection of dye is immediately followed by saline to propel the dye into the central circulation. Dye concentration in arterial blood was measured continuously with a Gilford densitometer.

Arterial blood pressure was recorded with a Statham P23D strain gauge connected to an 18-inch Cournand needle in a brachial artery. Mean pressure was obtained by electronic damping. Systemic vascular resistance was calculated as the ratio of mean arterial blood pressure to cardiac index. Arterial blood was collected in heparinized syringes anaerobically, and its oxygen and carbon dioxide tensions and $\mathrm{pH}$ were measured with oxygen and carbon dioxide electrodes (9) and a Metrohm $\mathrm{pH}$ meter at $37^{\circ} \mathrm{C}$. Forearm blood flow was measured by venous occlusion plethysmography with either Whitney mercury-in-rubber strain gauges or water-filled plethysmographs in which the water temperature was maintained at $34^{\circ} \mathrm{C}$. The mercury-in-rubber strain gauges were calibrated according to the method of Whitney (10). During measurement of forearm blood flow, the circulation to the hand was excluded by inflating a wrist cuff to $250 \mathrm{~mm} \mathrm{Hg}$. Forearm vascular resistance was calculated as the ratio of mean arterial blood pressure to forearm blood flow. Measurements of forearm blood flow were not made on the same day as were those of cardiac output.

To induce hypoxia, the subjects breathed $7.5 \%$ oxygen in nitrogen from a Douglas bag by means of a mouthpiece and low resistance valve system. Plasma concentrations of epinephrine and norepinephrine were measured by the trihydroxy indole method in six subjects during inhalation of room air and during the tenth minute of inhalation of $7.5 \%$ oxygen in nitrogen. The catecholamines were extracted from plasma with an alumina column as described by Crout (11) and differentially assayed by the procedure of Wiegand and Perry (12).

Beta-adrenergic blockade was produced in ten subjects by intravenous administration of 0.8 to $1.5 \mathrm{mg}$ per $\mathrm{kg}$ of pronethalol given over a period of 5 minutes. After its administration, intravenous infusion of $10 \mu \mathrm{g}$ per minute of epinephrine produced hypertension and bradycardia in each subject. The subsequent availability of propranolol, a more potent beta-adrenergic blocking drug (13), led us to study the effect of this agent on the changes in cardiac output, heart rate, and arterial blood pressure induced by hypoxia in seven additional subjects, using an experimental protocol identical to that for pronethalol, except that the subjects received $5 \mathrm{mg}$ of propranolol intravenously. 1

The effect of beta-adrenergic blockade on the general circulatory response to hypoxia was studied as follows: Control measurements of cardiac output, blood pressure, arterial blood gas tensions, and $\mathrm{pH}$ were made while the subjects breathed room air and were repeated during the seventh and eighth minutes of breathing $7.5 \%$ oxygen in nitrogen. After 15 minutes of recovery, betaadrenergic blockade was produced by intravenous administration of pronethalol or propranolol, and these

1 Pronethalol and propranolol were supplied through the courtesy of Dr. Alex Sahagian-Edwards of Ayerst Laboratories, New York, N. Y.

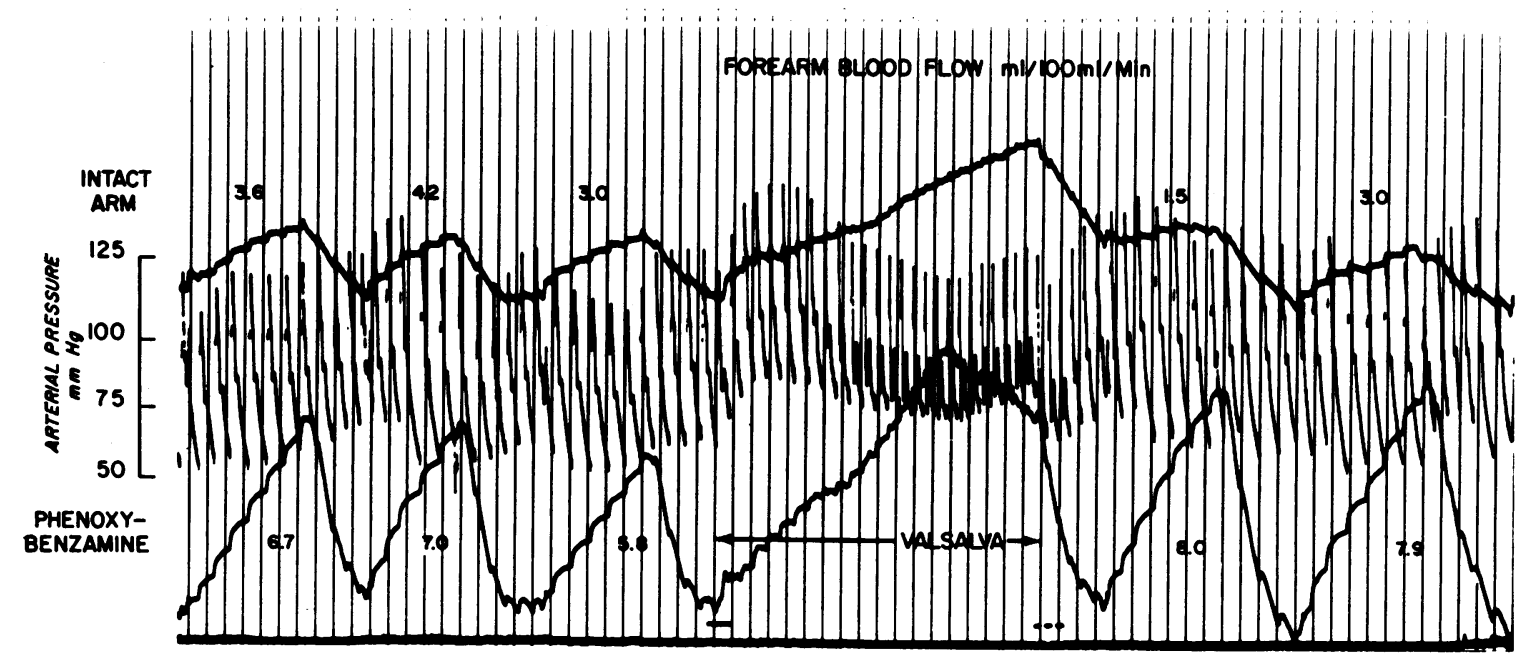

Fig. 1. Response of blood flow to the VAlsalva Maneuver in the intact and Phenoxybenzamine-treated FOREARM. In the intact arm, blood flow is reduced during the elevation of blood pressure that follows release of forced expiration against a closed glottis. In the opposite arm, no vasoconstriction occurs, demonstrating blockade of sympathetic neural vasoconstriction by $8 \mathrm{mg}$ of phenoxybenzamine administered intra-arterially. The numbers by each venous occlusion curve indicate forearm blood flow. 

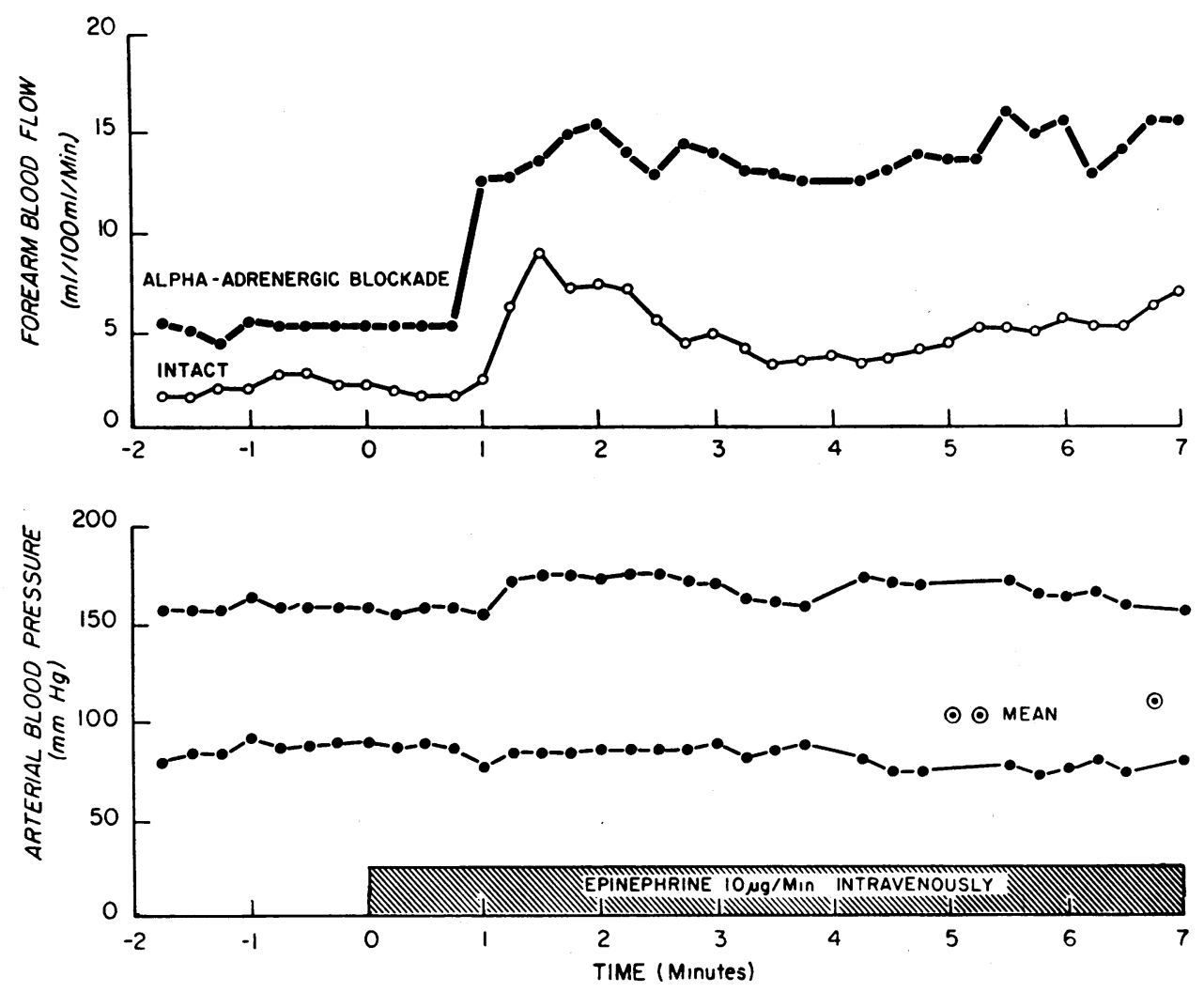

Fig. 2. EFFECT OF ALPHA-ADRENERGIC BLOCKADE (PHENOXYBENZAMINE) ON FOREARM VASCULAR RESPONSE TO EPINEPHRINE. Intravenously administered epinephrine produced a marked and prolonged increase in blood flow in the arm whose alpha-adrenergic receptors had been blocked by phenoxybenzamine, $8 \mathrm{mg}$ intra-arterially.

measurements were repeated while the subjects breathed room air and during the seventh and eighth minutes of $7.5 \%$ oxygen breathing.

Beta-adrenergic blockade of the forearm only was produced by the injection of $15 \mathrm{mg}$ of pronethalol into the brachial artery over a period of 5 minutes. After intraarterial administration of pronethalol, intravenous administration of $10 \mu \mathrm{g}$ per minute of epinephrine produced a slight decrease in forearm blood flow instead of the usual increase. Alpha-adrenergic blockade of the forearm was produced by the intra-arterial administration of $8 \mathrm{mg}$ of phenoxybenzamine over a period of $5 \mathrm{~min}$ utes. The effectiveness of blockade was verified by showing abolition of the decrease in forearm blood flow that normally accompanies the post-Valsalva "overshoot" in blood pressure (Figure 1). Roddie, Shepherd, and Whelan (14) have demonstrated that this decrease in forearm blood flow is mediated by increased activity of adrenergic sympathetic nerves. Figures 2 and 3 show the change in forearm blood flow induced by epinephrine, $10 \mu \mathrm{g}$ per minute intravenously, and the modification of this effect by blockade of alpha- and of alpha- and betaadrenergic receptors, respectively.
The effect of beta-adrenergic or alpha-adrenergic blockade of the forearm on its circulatory response to hypoxia was studied as follows: Beta-adrenergic or alpha-adrenergic blockade of the forearm was produced in one forearm. Blood flow was measured simultaneously in both forearms as the subjects breathed room air and during the first 8 minutes of breathing $7.5 \%$ oxygen in nitrogen. In seven additional experiments, blood flow was measured in only one arm after the intra-arterial administration of phenoxybenzamine and the response to hypoxia determined as noted above. After a 15-minute rest period, pronethalol was given intra-arterially into the brachial artery of the same arm and the response to hypoxia recorded again.

The results were analyzed statistically by comparing the mean difference between control and hypoxic measurements to zero by the $t$ test (15). In comparing the effects of hypoxia on intact forearm vessels with its effects after phenoxybenzamine, we used per cent change in blood flow and vascular resistance in statistical analysis because of the marked difference in blood flow through the intact and the phenoxybenzamine-treated extremity before hypoxia. 

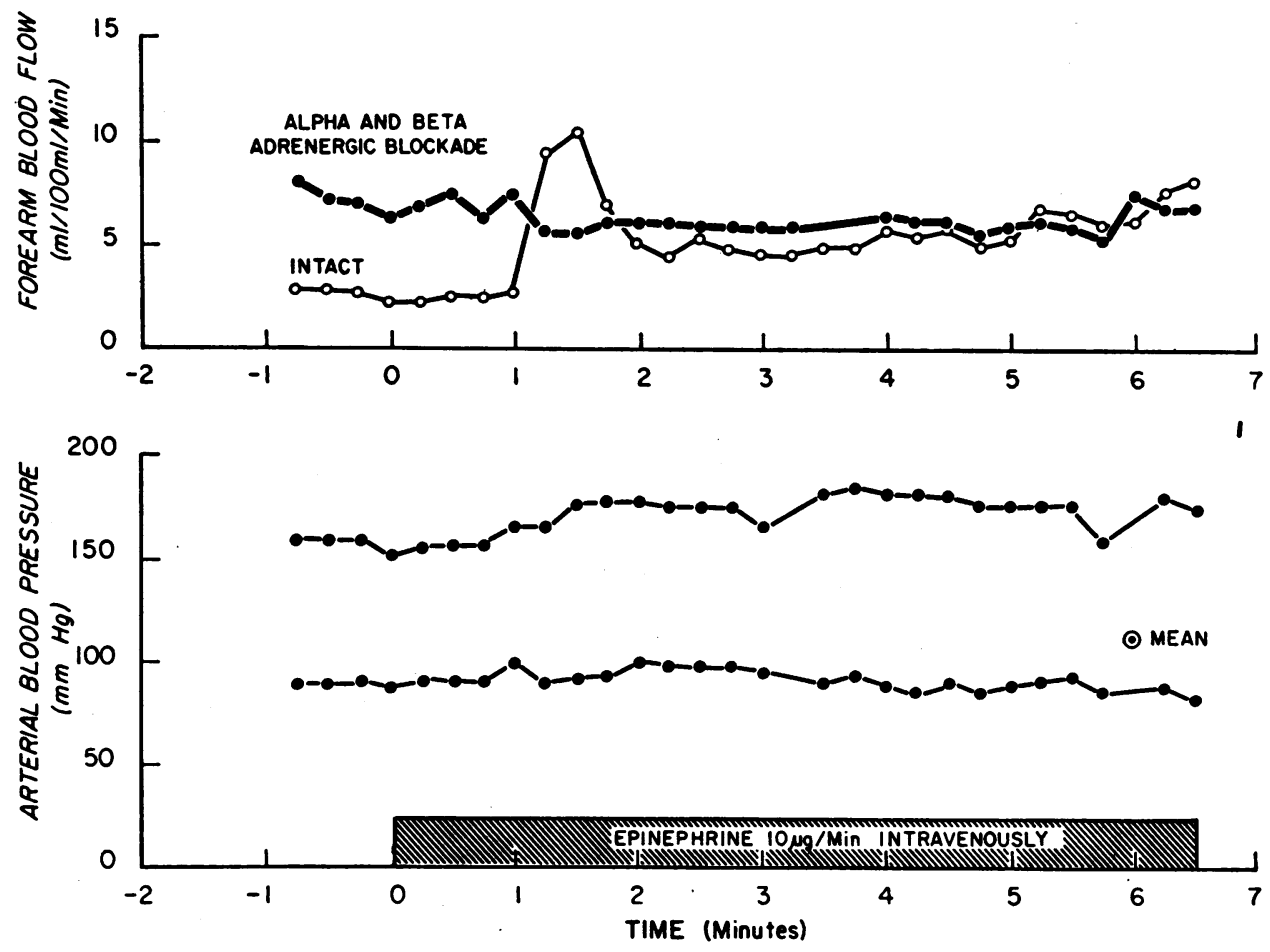

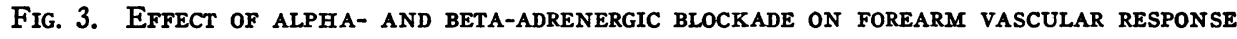
TO EPINEPHRINE. Blockade of both alpha- and beta-adrenergic receptors, by intra-arterial injection of propranolol, $0.2 \mathrm{mg}$, in the arm already treated with phenoxybenzamine, abolished the vasodilation produced before beta-adrenergic blockade by intravenous epinephrine (see Figure 2).

\section{Results}

Cardiac output, heart rate, and arterial blood pressure

As shown in Table I, before pronethalol, hypoxia with an average reduction in arterial oxygen tension from 90 to $34 \mathrm{~mm} \mathrm{Hg}$ produced a $54 \%$ increase in cardiac index, from 2.8 to $4.3 \mathrm{~L}$ per minute per $\mathrm{m}^{2}$. After beta-adrenergic blockade with pronethalol, reduction in arterial oxygen tension from 90 to $33 \mathrm{~mm} \mathrm{Hg}$ was accompanied by a smaller mean increase $(27 \%)$ in cardiac index,

TABLE I

Effects of pronethalol on circulatory responses to hypoxia*

\begin{tabular}{|c|c|c|c|c|c|c|c|c|c|c|c|}
\hline \multirow[b]{3}{*}{$\begin{array}{l}\text { Cardiac index, } \\
L / \min / m^{2}\end{array}$} & \multicolumn{5}{|c|}{ Intact } & \multicolumn{5}{|c|}{ Pronethalol } & \multirow[b]{2}{*}{$D_{1}-D_{2}$} \\
\hline & \multicolumn{2}{|c|}{ Room air } & \multicolumn{2}{|c|}{$7.5 \%$ oxygen } & Difference $D_{1}$ & \multicolumn{2}{|c|}{ Room air } & \multicolumn{2}{|c|}{$7.5 \%$ oxygen } & Difference $\mathrm{D}_{2}$ & \\
\hline & 2.8 & \pm 0.19 & 4.3 & \pm 0.2 & $\begin{array}{c}1.49 \pm 0.2 \\
p<0.001\end{array}$ & 2.6 & \pm 0.11 & 3.3 & \pm 0.14 & $\begin{array}{c}0.74 \pm 0.14 \\
p<0.001\end{array}$ & $\begin{array}{l}0.75 \pm 0.12 \\
p<0.001\end{array}$ \\
\hline $\begin{array}{l}\text { Heart rate, } \\
\text { beats/min }\end{array}$ & 72 & \pm 2.6 & 101 & \pm 3.1 & $\begin{array}{c}29 \quad \pm 3.4 \\
p<0.001\end{array}$ & 70 & \pm 2.4 & 91 & \pm 2.0 & $\begin{array}{c}21 \quad \pm 2.2 \\
p<0.001\end{array}$ & $\begin{array}{l}7.6 \pm 1.5 \\
p<0.001\end{array}$ \\
\hline $\begin{array}{l}\text { Mean arterial } \\
\text { pressure, } m \boldsymbol{m} \mathrm{Hg}_{\mathrm{g}}\end{array}$ & 91 & \pm 2.4 & 90 & \pm 2.6 & $\begin{array}{l}1.5 \pm 1.1 \\
p>0.1\end{array}$ & 89 & \pm 2.0 & 87 & \pm 2.4 & $\begin{array}{l}2.1 \pm 1.2 \\
p>0.1\end{array}$ & $\begin{array}{c}-0.6 \pm 1.7 \\
p>0.1\end{array}$ \\
\hline $\begin{array}{l}\text { Arterial blood } \\
\mathrm{O}_{2} \text { tension, } m m \mathrm{Hg}\end{array}$ & 90 & \pm 1.8 & 34 & \pm 0.9 & $\begin{aligned} 55 & \pm 1.9 \\
p & <0.001\end{aligned}$ & 90 & \pm 2.8 & 33 & \pm 0.9 & $\begin{array}{c}56 \quad \begin{array}{l} \pm .2 \\
p\end{array}<0.001\end{array}$ & $\begin{array}{c}-0.7 \pm 2.3 \\
p>0.1\end{array}$ \\
\hline $\begin{array}{l}\text { Arterial blood } \\
\quad \mathrm{CO}_{2} \text { tension, } m m \mathrm{Hg}_{\mathrm{g}}\end{array}$ & 39 & \pm 0.9 & 31 & \pm 1.0 & $\begin{array}{l}7.5 \pm 1.5 \\
p<0.001\end{array}$ & 39 & \pm 0.8 & 31 & \pm 1.0 & $\begin{array}{l}8.4 \pm 1.4 \\
p<0.001\end{array}$ & $\begin{array}{c}-0.9 \pm 0.8 \\
p>0.1\end{array}$ \\
\hline Arterial blood pH & 7.41 & \pm 0.01 & 7.50 & \pm 0.01 & $\begin{array}{c}0.086 \pm 0.01 \\
p<0.001\end{array}$ & 7.42 & \pm 0.01 & 7.50 & \pm 0.01 & $\begin{array}{c}0.082 \pm 0.01 \\
\mathrm{p}<0.001\end{array}$ & $\begin{array}{l}0.003 \pm 0.01 \\
p>0.1\end{array}$ \\
\hline
\end{tabular}

* All values are mean \pm standard error of ten experiments in ten subjects. 
TABLE II

Effects of propranolol on circulatory responses to hypoxia*

\begin{tabular}{|c|c|c|c|c|c|c|c|c|c|c|c|}
\hline \multirow[b]{3}{*}{$\begin{array}{l}\text { Cardiac index, } \\
L / \min / m^{2}\end{array}$} & \multicolumn{5}{|c|}{ Intact } & \multicolumn{5}{|c|}{ Propranolol } & \multirow{3}{*}{$\begin{array}{l}\mathrm{D}_{1}-\mathrm{D}_{2} \\
1.06 \pm 0.32 \\
\mathrm{p}<0.01\end{array}$} \\
\hline & \multicolumn{2}{|c|}{ Room air } & \multicolumn{2}{|c|}{$7.5 \%$ oxygen } & \multirow{2}{*}{$\begin{array}{c}\text { Difference } \mathrm{D}_{1} \\
1.74 \pm 0.37 \\
\mathrm{p}<0.005\end{array}$} & \multicolumn{2}{|c|}{ Room air } & \multicolumn{2}{|c|}{$7.5 \%$ oxygen } & \multirow{2}{*}{$\begin{array}{c}\text { Difference } \mathrm{D}_{2} \\
0.69 \pm 0.23 \\
\mathrm{p}<0.05\end{array}$} & \\
\hline & 2.8 & \pm 0.14 & 4.5 & \pm 0.33 & & 2.5 & \pm 0.23 & 3.1 & \pm 0.40 & & \\
\hline $\begin{array}{l}\text { Heart rate, } \\
\text { beats } / \min \end{array}$ & 70 & \pm 5.4 & 100 & \pm 4.8 & $\begin{array}{r}30 \quad \pm 5.9 \\
\mathrm{p}<0.005\end{array}$ & 61 & \pm 4.0 & 84 & \pm 4.1 & $\begin{array}{r}23 \quad \pm 4.4 \\
p<0.005\end{array}$ & $\begin{array}{l}6.9 \pm 5.9 \\
p>0.2\end{array}$ \\
\hline $\begin{array}{l}\text { Mean arterial } \\
\text { pressure, } m m \mathbf{H g}\end{array}$ & 97 & \pm 2.9 & 99 & \pm 6.0 & $\begin{array}{l}1.7 \pm 3.8 \\
p>0.5\end{array}$ & 97 & \pm 3.9 & 108 & \pm 6.5 & $\begin{aligned} 11 & \pm 5.5 \\
\mathrm{p} & >0.05\end{aligned}$ & $\begin{array}{l}-9.1 \pm 5.8 \\
\mathrm{p}>0.1\end{array}$ \\
\hline $\begin{array}{l}\text { Arterial blood } \\
\mathrm{O}_{2} \text { tension, } m m \mathrm{Hg}\end{array}$ & 96 & \pm 4.6 & 36 & \pm 2.6 & $\begin{array}{r}60 \quad \pm 4.0 \\
p<0.001\end{array}$ & 89 & \pm 4.0 & 35 & \pm 3.7 & $\begin{aligned} 53 & \pm 4.0 \\
\mathrm{p} & <0.001\end{aligned}$ & $\begin{array}{l}6.6 \pm 2.1 \\
\mathrm{p}<0.025\end{array}$ \\
\hline $\begin{array}{l}\text { Arterial blood } \\
\qquad \mathrm{CO}_{2} \text { tension, } m m \mathrm{Hg}\end{array}$ & 34 & \pm 0.7 & 25 & \pm 0.8 & $\begin{array}{c}8.7 \pm 0.7 \\
p<0.001\end{array}$ & 36 & \pm 0.6 & 25 & \pm 1.5 & $\begin{array}{r}11 \quad \pm 1.9 \\
\mathrm{p}\end{array}$ & $\begin{array}{c}-2.4 \pm 1.4 \\
p>0.1\end{array}$ \\
\hline Arterial blood pH & 7.45 & \pm 0.006 & 7.54 & \pm 0.01 & $\begin{array}{c}0.09 \pm 0.008 \\
p<0.001\end{array}$ & 7.43 & \pm 0.01 & 7.57 & \pm 0.02 & $\begin{array}{l}0.14 \pm 0.02 \\
p<0.001\end{array}$ & $\begin{array}{c}-0.05 \pm 0.01 \\
\mathrm{p}<0.02\end{array}$ \\
\hline
\end{tabular}

* Figures are mean \pm standard error of seven experiments in seven subjects.

from 2.6 to $3.3 \mathrm{~L}$ per minute per $\mathrm{m}^{2}$. A smaller change in output occurred in each of the ten subjects after beta-adrenergic blockade. Similarly, heart rate increased $41 \%$, from 72 to 101 beats per minute, during hypoxia before beta-adrenergic blockade, but only $30 \%$, from 70 to 91 beats per minute, after pronethalol. The increases in both cardiac output and heart rate induced by hypoxia were significantly $(p<0.01)$ less pronounced after pronethalol. Arterial pressure did not change significantly during hypoxia before or after pronethalol. Systemic vascular resistance fell from 34 to $26 \mathrm{~mm} \mathrm{Hg}$ per $\mathrm{L}$ per minute per $\mathrm{m}^{2}$ during hypoxia after pronethalol, the decrease occurring with pronethalol being significantly $(p<0.01)$ less than the decrease from 33 to $21 \mathrm{~mm} \mathrm{Hg}$ per $\mathrm{L}$ per minute per $\mathrm{m}^{2}$, which occurred during hypoxia before pronethalol. Changes in arterial $\mathrm{CO}_{2}$ tension and $\mathrm{pH}$ induced by hypoxia were similar before and after pronethalol.

In the seven subjects who received propranolol, hypoxia before beta-adrenergic blockade was associated with a $62 \%$ increase in cardiac index, from 2.8 to $4.5 \mathrm{~L}$ per minute per $\mathrm{m}^{2}$, and a $43 \%$ increase in heart rate, from 70 to 100 beats per minute (Table II). After administration of propranolol, inhalation of $7.5 \%$ oxygen produced only a $28 \%$ increase in cardiac index, from 2.5 to 3.1 $\mathrm{L}$ per minute per $\mathrm{m}^{2}$, and a $38 \%$ increase in heart rate, from 61 to 84 beats per minute, despite reduction in arterial oxygen tension below that in the control experiments.

Five additional subjects breathed $7.5 \%$ oxygen twice, without any blocking agent, to evaluate the possibility that the second exposure to hypoxia might produce less rise in cardiac output and heart rate than did the first, even though no blocking drug had been given. Cardiac index increased an average of $1.4 \pm 0.6$ (SEM) L per minute per $\mathrm{m}^{2}$ during the first exposure to $7.5 \%$ oxygen, and $1.5 \pm 0.4 \mathrm{~L}$ per minute per $\mathrm{m}^{2}$ during the second. Heart rate increased $30 \pm 5$ and $28 \pm 4$

TABLE III

Plasma concentrations of catecholamines*

\begin{tabular}{lccccc}
\hline & Room air & $7.5 \%$ oxygen & Difference & p \\
\hline $\begin{array}{l}\text { Epinephrine, } \\
\mu g / L\end{array}$ & $0.067 \pm 0.066$ & $0.13 \pm 0.07$ & $0.067 \pm 0.11$ & $>0.5$ \\
$\begin{array}{l}\text { Norepinephrine, } \\
\mu g / L\end{array}$ & $1.45 \pm 0.56$ & $0.82 \pm 0.47$ & $0.63 \pm 0.39$ & $>0.1$ \\
$\begin{array}{l}\text { Arterial oxygen } \\
\text { tension, } m m H g\end{array}$ & $97 \quad \pm 1.8$ & $32 \pm 2.7$ & $64 \quad \pm 1.9$ & $<0.001$ \\
\hline
\end{tabular}

${ }^{*}$ Figures are mean \pm standard error of six experiments in six subjects. 
TABLE IV

Effects of pronethalol on forearm vascular response to hypoxia*

\begin{tabular}{|c|c|c|c|c|c|c|c|c|c|c|c|}
\hline & \multicolumn{5}{|c|}{ Intact } & \multicolumn{5}{|c|}{ Pronethalol } & \multirow[b]{2}{*}{$D_{1}-D_{2}$} \\
\hline & \multicolumn{2}{|c|}{ Room air } & \multicolumn{2}{|c|}{$7.5 \%$ oxygen } & \multirow{2}{*}{$\begin{array}{l}\text { Difference } \mathrm{D}_{\mathbf{1}} \\
\begin{array}{l}0.83 \pm 0.2 \\
\mathrm{p}<\mathbf{0 . 0 2}\end{array}\end{array}$} & \multicolumn{2}{|c|}{ Room air } & \multicolumn{2}{|c|}{$7.5 \%$ oxygen } & Difference $\mathrm{D}_{2}$ & \\
\hline $\begin{array}{l}\text { Forearm blood } \\
\quad \text { flow, } \mathrm{ml} / 100 \mathrm{ml} / \mathrm{min}\end{array}$ & & \pm 0.4 & & $2 \pm 0.6$ & & & \pm 0.3 & & \pm 0.5 & $\begin{array}{l}0.78 \pm 0.2 \\
\mathrm{p}<0.05\end{array}$ & $\begin{array}{l}0.05 \pm 0.29 \\
p>0.4\end{array}$ \\
\hline $\begin{array}{l}\text { Forearm vascular } \\
\text { resistance, } \mathrm{mm} \mathrm{Hg} / \\
\mathrm{ml} / 100 \mathrm{ml} / \mathrm{min}\end{array}$ & 42 & \pm 6.8 & 32 & \pm 4.6 & $\begin{array}{rl}10 & \mathrm{p}\end{array} \underset{0.02}{0.7}$ & 28 & \pm 2.6 & 23 & \pm 2.4 & $\begin{array}{l}5.0 \pm 1.3 \\
\mathrm{p}<0.02\end{array}$ & $\begin{array}{c}5.3 \pm 3.2 \\
p>0.1\end{array}$ \\
\hline $\begin{array}{l}\text { Arterial blood } \\
\mathrm{O}_{2} \text { tension, } m m ~ H g\end{array}$ & 93 & \pm 1.3 & 35 & \pm 1.0 & $\begin{aligned} 58 & \geq 1.6 \\
\mathrm{p} & <0.001\end{aligned}$ & 93 & \pm 1.3 & 35 & \pm 1.0 & \pm 1.6 & $0 \dagger$ \\
\hline $\begin{array}{l}\text { Arterial blood } \\
\mathrm{CO}_{2} \text { tension, } m m \mathrm{Hg}\end{array}$ & 39 & \pm 1.5 & 32 & \pm 0.9 & $\begin{array}{l}7.4 \pm 1.3 \\
\mathrm{p}<0.005\end{array}$ & 39 & \pm 1.5 & 32 & \pm 0.9 & $7.4 \pm 1.3$ & $0 \dagger$ \\
\hline
\end{tabular}

* Data are mean \pm standard error of six experiments in six subjects. arterially.

† Flow was measured simultaneously in both arms, into one of which $15 \mathrm{mg}$ pronethalol had been injected intra-

beats per minute, respectively, whereas arterial oxygen tension fell $57 \pm 4$ and $53 \pm 4 \mathrm{~mm} \mathrm{Hg}$ during the first and second exposures to hypoxia.

\section{Plasma concentrations of catecholamines during hypoxia}

As shown in Table III, hypoxia induced by breathing $7.5 \%$ oxygen for 8 minutes produced no significant change in the plasma concentrations of epinephrine or norepinephrine in six subjects, despite a reduction in average oxygen tension of arterial blood from 97 to $33 \mathrm{~mm} \mathrm{Hg}$.

\section{Pharmacologic modification of forearm vascular} response to hypoxia

A) Blockade of beta-adrenergic receptors. As shown in Table IV, blood flow in the intact forearm increased by $35 \%$, from 2.4 to $3.2 \mathrm{ml}$ per $100 \mathrm{ml}$ per minute, in six subjects during inhalation of $7.5 \%$ oxygen, a change not significantly greater than the $25 \%$ increase (from 3.2 to $4.0 \mathrm{ml}$ per $100 \mathrm{ml}$ per minute) in blood flow in the opposite arm after intra-arterial injections of pronethalol in a dose that completely blocked the vasodilation induced by intravenously adminis-

TABLE V

Effects of phenoxybenzamine on forearm vascular response to hypoxia*

\begin{tabular}{|c|c|c|c|c|c|c|c|}
\hline & \multicolumn{3}{|c|}{ Intact } & \multicolumn{3}{|c|}{ Phenoxybenzamine } & \multirow[b]{2}{*}{$D_{1}-D_{2}$} \\
\hline & Room air & $7.5 \%$ oxygen & $\overline{\text { Difference } \mathrm{D}_{1}}$ & Room air & $7.5 \%$ oxygen & Difference $D_{2}$ & \\
\hline $\begin{array}{l}\text { Forearm blood } \\
\text { flow, } \mathrm{ml} / 100 \mathrm{ml} / \mathrm{min}\end{array}$ & $2.2 \pm 0.4$ & $2.8 \pm 0.6$ & $\begin{array}{l}0.6 \pm 0.18 \\
\mathrm{p}<0.025\end{array}$ & $6.1 \pm 1.2$ & $7.8 \pm 0.3$ & $\begin{array}{l}1.7 \pm 0.46 \\
\mathrm{p}<0.02\end{array}$ & $\begin{array}{l}-1.1 \pm 0.23 \\
\mathrm{p}<0.005\end{array}$ \\
\hline Per cent change & & & +27 & & & +28 & $p \stackrel{+1 \pm 1}{p}=0.3$ \\
\hline $\begin{array}{l}\text { Forearm vascular } \\
\text { resistance, } \mathrm{mm} \mathrm{Hg} / \\
\mathrm{ml} / 100 \mathrm{ml} / \mathrm{min}\end{array}$ & $53 \pm 11$ & $41 \pm 8$ & $\begin{aligned} 11.5 & \pm 3 \\
p & <0.02\end{aligned}$ & $18 \pm 3$ & $12 \pm 2$ & $\begin{array}{l}5.8 \pm 2 \\
p<0.05\end{array}$ & $\begin{array}{l}5.7 \pm 3.2 \\
\mathrm{p}>0.1\end{array}$ \\
\hline Per cent change & & & -21 & & & -29 & $\begin{array}{l}-8 \\
p>0.2\end{array}$ \\
\hline $\begin{array}{l}\text { Arterial blood } \\
\mathrm{O}_{2} \text { tension, } m m ~ H g\end{array}$ & $91.8 \pm 2.3$ & $40.7 \pm 5.2$ & $\begin{array}{c}51.2 \pm 4.2 \\
\mathrm{p}<0.001\end{array}$ & $91.8 \pm 2.3$ & $40.7 \pm 5.2$ & $\begin{array}{c}51.2 \pm 4.2 \\
\mathrm{p}<0.001\end{array}$ & $0 \dagger$ \\
\hline $\begin{array}{l}\text { Arterial blood } \\
\mathrm{CO}_{2} \text { tension, } m m \mathrm{Hg}\end{array}$ & $38 \pm 1.1$ & $29 \pm 1.7$ & $\begin{array}{l}8.5 \pm 1.2 \\
p<0.001\end{array}$ & $38 \pm 11$ & $29 \pm 1.7$ & $\begin{array}{l}8.5 \pm 1.2 \\
p<0.001\end{array}$ & $0 \dagger$ \\
\hline
\end{tabular}

* Data are mean \pm standard error of six experiments in six subjects. arterially.

$\dagger$ Blood flow was measured simultaneously in both arms, into one of which pronethalol had been injected intra- 
TABLE VI

Effects of alpha- and beta-adrenergic blockade on forearm vascular response to hypoxia*

\begin{tabular}{|c|c|c|c|c|c|c|c|}
\hline & \multicolumn{3}{|c|}{ Phenoxybenzamine } & \multicolumn{3}{|c|}{ Phenoxybenzamine and pronethalol } & \multirow[b]{2}{*}{$D_{1}-D_{2}$} \\
\hline & Room air & $7.5 \%$ oxygen & Difference $D_{1}$ & Room air & $7.5 \%$ oxygen & $\overrightarrow{\text { Difference } \mathrm{D}_{2}}$ & \\
\hline $\begin{array}{l}\text { Forearm blood } \\
\quad \text { flow, } \mathrm{ml} / 100 \mathrm{ml} / \mathrm{min}\end{array}$ & $7.7 \pm 2.0$ & $9.6 \pm 2.1$ & $\begin{array}{l}1.9 \pm 0.4 \\
p<0.01\end{array}$ & $6.4 \pm 1.7$ & $8.6 \pm 1.8$ & $\begin{array}{l}2.2 \pm 0.3 \\
p<0.001\end{array}$ & $\begin{array}{l}-0.2 \pm 0.2 \\
\mathrm{p}>0.3\end{array}$ \\
\hline $\begin{array}{l}\text { Forearm vascular } \\
\text { resistance, } \mathrm{mm} \\
\mathrm{ml} / 100 \mathrm{ml} / \mathrm{min}\end{array}$ & $15.7 \pm 2.8$ & $11.0 \pm 1.8$ & $\begin{array}{l}4.7 \pm 1.6 \\
p<0.05\end{array}$ & $18.9 \pm 4.3$ & $13.1 \pm 2.6$ & $\begin{array}{l}5.7 \pm 1.9 \\
p<0.05\end{array}$ & $\begin{array}{c}-1.0 \pm 0.6 \\
p>0.1\end{array}$ \\
\hline $\begin{array}{l}\text { Arterial blood } \\
\mathrm{O}_{2} \text { tension, } m m \mathrm{Hg}\end{array}$ & $91 \pm 2.1$ & $42 \pm 2.7$ & $\begin{aligned} 49 & \pm 3.4 \\
\mathrm{p} & <0.001\end{aligned}$ & $96 \pm 3.7$ & $38 \pm 1.5$ & $\begin{aligned} 58 & \pm 2.8 \\
\mathrm{p} & <0.001\end{aligned}$ & $\begin{array}{l}-9.1 \pm 3.6 \\
\mathrm{p}<0.05\end{array}$ \\
\hline $\begin{array}{l}\text { Arterial blood } \\
\mathrm{CO}_{2} \text { tension, } m m ~ H g\end{array}$ & $38 \pm 1.1$ & $27 \pm 2.5$ & $\begin{aligned} 11 & \pm 1.9 \\
\mathrm{p} & <0.01\end{aligned}$ & $35 \pm 1.9$ & $30 \pm 1.5$ & $\begin{array}{l}5 \leq 1.3 \\
\mathrm{p}<0.01\end{array}$ & $\begin{array}{c}+5.6 \pm 2.1 \\
p<0.05\end{array}$ \\
\hline
\end{tabular}

* Data are mean \pm standard error of seven experiments in seven subjects.

tered epinephrine, $10 \mu \mathrm{g}$ per minute. Vascular resistance in the intact forearm decreased by $25 \%$, from 42 to $32 \mathrm{~mm} \mathrm{Hg}$ per $\mathrm{ml}$ per $100 \mathrm{ml}$ per minute. In the pronethalol-treated forearm, hypoxia reduced vascular resistance from 28 to $23 \mathrm{~mm} \mathrm{Hg}$ per $\mathrm{ml}$ per $100 \mathrm{ml}$ per minute, a change not significantly different from that in the intact arm.

B) Blockade of alpha-adrenergic receptors. Table V compares the effects of hypoxia on blood flow in the intact and phenoxybenzamine-treated forearms of six subjects. Forearm blood flow increased 27 and $28 \%$ in the forearms during exposure to $7.5 \% \mathrm{O}_{2}$. Forearm vascular resistance decreased $29 \%$ in the forearm that had received phenoxybenzamine and $21 \%$ in the intact forearm, but the difference was not statistically significant.

C) Blockade of both alpha-and beta-adrenergic receptors. Administration of phenoxybenzamine in the above experiments produced a large increase in forearm blood flow and decrease in forearm vascular resistance, so that the state of the blood vessels, in particular their caliber, in the intact and phenoxybenzamine-treated forearm was substantially different. To exclude the possibility that this factor influenced the results, we observed the forearm vascular response to hypoxia in seven additional experiments in the same forearm, first after alpha-adrenergic blockade and then after blockade of both alpha- and beta-adrenergic receptors. The increase in forearm blood flow and decrease in forearm vascular resistance during hypoxia were not significantly different with phenoxybenzamine plus pronethalol from the corresponding changes seen with phenoxybenzamine alone, although the decrease in arterial oxygen tension was slightly greater with phenoxybenzamine plus pronethalol (Table VI).

\section{Discussion}

Circulating catecholamines. The data presented provide evidence that the circulatory responses to acute hypoxia in man are not the result of increased concentration of circulating catecholamines. This view is based on the following: 1) Blockade of alpha-adrenergic receptors in the forearm did not modify the vasodilator response to hypoxia, although it enhanced considerably the vasodilator response to intravenous epinephrine. 2) Beta-adrenergic blockade in the forearm did not alter the vasodilator response to hypoxia, although it completely blocked the vasodilator response to intravenous epinephrine. 3) Plasma epinephrine and norepinephrine concentrations did not change significantly during hypoxia in our experiments or in studies by Goldring and his associates (16), who used less severe hypoxia.

Extremity circulation. Although the administration of phenoxybenzamine blocked the effects of increased activity of sympathetic vasoconstrictor nerves in the forearm, as shown by modification of the response to the Valsalva maneuver, phenoxybenzamine did not modify the response to hypoxia. Thus adrenergic sympathetic nerves appear to play little role in the forearm vascular response to hypoxia.

Our study did not reveal the mechanism of forearm vasodilation during hypoxia. Black and Roddie (17) suggested that vasodilation in the forearm during hypoxia is due to the accom- 
panying hypocapnia, because the vasodilation was reduced when carbon dioxide was added to the inspired low-oxygen gas mixture. As reported elsewhere (18), this conclusion was not justified, because when carbon dioxide was added to the inspired hypoxia gas mixture, alveolar ventilation increased with consequent substantial increase in the mean arterial blood oxygen tension (from 37 to $52 \mathrm{~mm} \mathrm{Hg}$ ). When arterial blood $\mathrm{CO}_{2}$ tension was maintained at the control level, and at the same time the concentration of inspired oxygen reduced to bring the arterial blood oxygen tension to the same level as during hypocapnic hypoxia, the vasodilator response to hypoxia without hypocapnia was equal to that during hypocapnic hypoxia (18). Thus, hypocapnia cannot account for the forearm vasodilation induced by hypoxia.

Animal experiments suggest that hypoxic vasodilation in skeletal muscle results from a direct effect of hypoxia on the smooth muscle of the high resistance blood vessels (19) or from release of vasodilator metabolites from the hypoxic tissues, which in turn dilate the high resistance blood vessels. In this respect, Imai, Riley, and Berne (20) showed that adenosine appears in hypoxic cardiac muscle but not in hypoxic skeletal muscle. Hence adenosine cannot be the cause of hypoxic vasodilation in skeletal muscle.

Cardiac output. Blockade of beta-adrenergic receptors reduced by about half the elevation in cardiac output and heart rate produced by hypoxia. Since the plasma concentration of catecholamines did not increase measurably in our experiments, and since the responses of the forearm vascular bed to hypoxia are not consistent with an increased blood concentration of catecholamines, the modification by beta-adrenergic blocking agents of the circulatory effects of hypoxia can be reasonably attributed to blockade of the effect of cardiac sympathetic nerves. This conclusion is consistent with the findings of Downing and Siegel (21) that systemic hypoxia in the cat results in marked increase in cardiac sympathetic discharge via the inferior cardiac nerve.

Beta-adrenergic blockade reduced but did not abolish completely the increase in cardiac output and heart rate induced by hypoxia. This may be the result of incomplete blockade of the effects of cardiac sympathetic nerves or of the operation of additional mechanisms leading to elevation of car- diac output during hypoxia. Increased venous return due to venoconstriction (22) and the resulting operation of the Frank-Starling mechanism, release of vagal inhibition, and a response by the heart to the peripheral vasodilation and lowered systemic vascular resistance induced by hypoxia are obvious possibilities.

The conclusion that blockade of the effects of increased stimulation of cardiac sympathetic nerves modifies the circulatory effects of hypoxia differs from that of previous workers. Harris, Bishop, and Segel (23) found that guanethidine, in a dose sufficient to abolish the post-Valsalva "overshoot" in arterial blood pressure, did not modify the cardiovascular responses to the hypoxia induced by breathing $13 \%$ oxygen. The increases in cardiac output and heart rate observed by these authors during hypoxia were small before administration of guanethidine and insignificant during the effect of guanethidine. It is possible, therefore, that the lack of significant effect of guanethidine may have been related to the mildness of the hypoxia, which resulted in circulatory changes of insufficient magnitude. Chidsey, Frye, Kahler, and Braunwald (24) found no significant difference in the changes in cardiac output and heart rate induced by inhalation of $12 \%$ oxygen before and after syrosingopine. Inability to evaluate the efficacy of sympathetic blockade with syrosingopine and incomplete understanding of the mechanisms of action of reserpine analogs complicate interpretation of their results.

Afferent and central nervous pathways by which hypoxia could stimulate cardiac sympathetic nerves in man are uncertain. In the dog the primary effects of perfusion of the carotid chemoreceptors with hypoxic blood are bradycardia, decrease in cardiac output, and peripheral vasoconstriction $(25,26)$. Thus, in the dog the carotid chemoreceptors do not form the afferent limb responsible for stimulation of cardiac sympathetic nerves during systemic hypoxia, which is accompanied by tachycardia and increased cardiac output: Downing, Mitchell, and Wallace (27) have suggested that the central nervous system itself is the receptor area responsible for cardiac sympathetic nerve discharge during hypoxia. The elevation in cardiac output and heart rate during systemic hypoxia in the dog is, to a large extent, secondary to increase in ventilation, acting by reflex mecha- 
nisms related to inflation of the lung (28). Increased ventilation is not a likely cause of the circulatory changes during hypoxia in man, since vigorous voluntary hyperventilation during which hypocapnia is prevented does not altar cardiac output or heart rate (29).

\section{Acknowledgments}

Miss Sandra Baker and Mesdames Barbara Richardson, Barbara Turlington, Rela White, Alice Wells, and Thelma Burton provided expert technical assistance, and Miss C. Canfield Smith expert secretarial assistance. We are particularly grateful to Dr. John DeVanzo and Mr. R. T. Ruckert of the A. H. Robins Co. for performing the fluorimetric assays of catecholamine concentrations in plasma.

\section{References}

1. Korner, P. I. Circulatory adaptations in hypoxia. Physiol. Rev. 1959, 39, 687.

2. Abramson, D. I., H. Landt, and J. E. Benjamin. Peripheral vascular response to acute anoxia. Arch. intern. Med. 1943, 71, 583.

3. Allwood, M. J., E. W. Keck, R. J. Marshall, and J. T. Shepherd. Correlation of hemodynamic events during infusion of epinephrine in man. J. appl. Physiol. 1962, 17, 71.

4. Swan, H. J. C. Some aspects of the action of adrenaline on the human circulation. St. Thomas's Hosp. Gaz. 1949, 47, 95.

5. Harrison, T. S., and J. Seaton. The relative effects of hypoxia and hypercarbia on adrenal medullary secretion in anesthetized dogs. J. Surg. Res. 1965, 5, 560.

6. Bousvaros, G. A., W. H. Palmer, P. Sekelj, and M. McGregor. Comparison of central and peripheral injection sites in the estimation of cardiac output by dye dilution curves. Circulat. Res. 1963, 12, 317.

7. Hetzel, P. S., H. J. C. Swan, and E. H. Wood. Influence of injection site on arterial dilution curves of T-1824. J. appl. Physiol. 1954, 7, 66.

8. Richardson, D. W., E. M. Wyso, A. M. Hecht, and D. P. Fitzpatrick. Value of continuous photoelectric recording of dye curves in the estimation of cardiac output. Circulation 1959, 20, 1111.

9. Severinghaus, J. W., and A. F. Bradley. Electrodes for blood $\mathrm{pO}_{2}$ and $\mathrm{pCO}_{2}$ determination. J. appl. Physiol. 1958, 13, 515.

10. Whitney, R. J. The measurement of volume changes in human limbs. J. Physiol. (Lond.) 1953, 121, 1.

11. Crout, J. R. Catechol amines in urine in Standard Methods of Clinical Chemistry, D. Seligson, Ed. New York, Academic Press, 1961, vol. 3, p. 62.

12. Wiegand, R. G., and J. E. Perry. Effect of L-DOPA and $\mathrm{N}$-methyl-N-benzyl-2-propynylamine $\cdot \mathrm{HCl}$ on DOPA, dopamine, norepinephrine, epinephrine, and serotonin levels in mouse brain. Biochem. Pharmacol. 1961, 7, 181.
13. Prichard, B. N. C., and P. M. S. Gillam. Use of propranolol (Inderal) in treatment of hypertension. Brit. med. J. 1964, 2, 725.

14. Roddie, I. C., J. T. Shepherd, and R. F. Whelan. Reflex changes in human skeletal muscle blood flow associated with changes in intrathoracic pressure changes. Circulat. Res. 1958, 6, 232.

15. Bailey, N. T. J. Statistical Methods in Biology. London, English Universities Press, 1959, p. 46.

16. Goldring, R. M., G. M. Turino, G. Cohen, A. G. Jameson, B. G. Bass, and A. P. Fishman. The catecholamines in the pulmonary arterial pressor response to acute hypoxia. J. clin. Invest. 1962, $41,1211$.

17. Black, J. E., and I. C. Roddie. The mechanism of the changes in forearm vascular resistance during hypoxia. J. Physiol. (Lond.) 1958, 143, 226.

18. Richardson, D. W., H. A. Kontos, W. Shapiro, and J. L. Patterson, Jr. Role of hypocapnia in the circulatory responses to acute hypoxia in man. J. appl. Physiol. 1966, 21, 22.

19. Ross, J. M., H. M. Fairchild, J. F. Weldy, and A. C. Guyton. Autoregulation of blood flow by oxygen lack. Amer. J. Physiol. 1962, 202, 21.

20. Imai, S., A. L. Riley, and R. M. Berne. Effect of ischemia on adenine nucleotides in cardiac and skeletal muscle. Circulat. Res. 1964, 15, 443.

21. Downing, S. E., and J. H. Siegel. Some factors concerned with the regulation of sympathetic discharge to the heart. Clin. Res. 1962, 10, 171.

22. Eckstein, J. W., and A. W. Horsley. Effects of hypoxia on peripheral venous tone in man. J. Lab. clin. Med. 1960, 56, 847.

23. Harris, P., J. M. Bishop, and N. Segel. The influence of guanethidine on hypoxic pulmonary hypertension in normal man. Clin. Sci. 1961, 21, 295.

24. Chidsey, C. A., R. L. Frye, R. L. Kahler, and E. Braunwald. Influences of syrosingopine on the cardiovascular response to acute hypoxemia and exercise. Circulat. Res. 1961, 9, 989.

25. Daly, M. De B., and M. J. Scott. The cardiovascular responses to stimulation of the carotid body chemoreceptors in the dog. J. Physiol. (Lond.) 1963, 165, 179.

26. Downing, S. E., J. P. Remensnyder, and J. H. Mitchell. Cardiovascular responses to hypoxic stimulation of the carotid bodies. Circulat. Res. 1962, 10, 676.

27. Downing, S. E., J. H. Mitchell, and A. G. Wallace. Cardiovascular responses to ischemia, hypoxia and hypercapnia of the central nervous system. Amer. J. Physiol. 1963, 204, 881.

28. Kontos, H. A., H. P. Mauck, Jr., D. W. Richardson, and J. L. Patterson, Jr. Mechanisms of circulatory responses to systemic hypoxia in the anesthetized dog. Amer. J. Physiol. 1965, 209, 397.

29. Richardson, D. W., A. J. Wasserman, and J. L. Patterson, Jr. General and regional circulatory responses to change in blood $\mathrm{pH}$ and carbon dioxide tension. J. clin. Invest. 1961, 40, 31. 